\title{
Cold-blooded divers: temperature-dependent dive performance in the wild hawksbill turtle Eretmochelys imbricata
}

\author{
Sandra Storch ${ }^{1, *}$, Rory P. Wilson ${ }^{1}$, Zandy-Marie Hillis-Starr ${ }^{2}$, Dieter Adelung ${ }^{1}$ \\ ${ }^{1}$ Leibniz-Institut für Meereswissenschaften, Experimentelle Ökologie, Düsternbrooker Weg 20, 24105 Kiel, Germany \\ ${ }^{2}$ National Park Service, Buck Island Reef National Monument, Christiansted, St. Croix, US Virgin Islands 00820, USA
}

\begin{abstract}
Sea turtles are diving ectotherms that are influenced by the temperature of the ambient water, although swimming activity can temper this influence via increased body temperatures enhanced by the thermal inertia of these large animals. We successfully equipped 3 nesting hawksbill turtles Eretmochelys imbricata with time-depth recorders (TDRs) to monitor water temperature and dive depth over the duration of the re-migration interval between 2 successive nesting seasons. Data sets for up to 22 mo were obtained, showing fluctuations in water temperature over the seasons. Nocturnal dive behaviour of the turtles at their foraging grounds revealed an increase in dive duration with decreasing water temperatures in winter. A model is provided to estimate dive duration for the range of temperatures experienced by this species in the wild. The data on vertical velocity during ascent and descent phases as a parameter for activity failed to show thermal dependence. It is concluded that changes in water temperature have an effect on the behavioural ecology of hawksbill turtles.
\end{abstract}

KEY WORDS: Hawksbill turtle $\cdot$ Eretmochelys imbricata $\cdot$ Water temperature $\cdot$ Dive behaviour $\cdot$ Dive duration $\cdot$ Thermal dependence $\cdot Q_{10}$

\section{INTRODUCTION}

Studies of the diving behaviour of air-breathing aquatic animals provide insight into the physiological constraints shaping species behaviour, distribution and ecology. In animals that are highly aquatic and constantly diving, behavioural aspects, such as the duration of dives, are most probably optimised and thus reveal the physiological limits of the animal in its environment. Sea turtles are excellent subjects for such studies because, unlike some freshwater species (e.g. Girgis 1961, Priest \& Franklin 2002), they rely entirely on gas exchange at the water surface. In contrast to most diving endotherms, sea turtles have a time budget that is constantly and extremely biased towards time spent submerged (e.g. Lutz \& Bentley 1985). Hawksbill turtles have been found to spend 95\% (inter-nesting females) to $97 \%$ (immatures) of their time under water (Storch 2003). Compared to many reptile species, these animals are large and very active (Jackson \& Prange 1979, Lutz \& Bentley 1985). The extreme body size of the leatherback turtle Dermochelys coriacea and its previously studied gigantothermy (Paladino et al. 1990, Davenport 1998) make it desirable to differentiate between the families Dermochelidae and the smaller Cheloniidae. However, even species of the latter family are capable of maintaining their body temperatures above that of the surrounding water during activity, with the huge pectoralis muscles being up to $7^{\circ} \mathrm{C}$ above water temperature (Heath \& McGinnis 1980, Standora et al. 1982, Spotila \& Standora 1985, Sato et al. 1994). Animals the size of sea turtles have high, internal, heat-storage capacities and therefore large thermal inertia. In addition, the green turtle Chelonia mydas is capable of controlling heat exchange with the environment through 
variable blood circulation in the front flippers (Hochscheid et al. 2002). Although such studies have not been conducted on the hawksbill turtle Eretmochelys imbricata to date, it is probable that this species adheres to similar patterns, despite its smaller size.

During periods characterised by resting behaviour only a limited amount of energy is used for movement. Therefore resting sea turtles in particular can be expected to show clear physiological responses to different temperatures; to date, changes exhibited in blood gas and $\mathrm{pH}$, duration of gastric and intestinal digestion, intestinal glucose transport, frequency of gastric contractions, probable digestive efficiency, activity, duration of inter-nesting intervals and metabolic rate have been shown (Skoczylas 1978, Lutz et al. 1989, Moon et al. 1997, Sato et al. 1998, Hays et al. 2002). In this context, the temperature quotient $Q_{10}$ is important in describing the response of metabolism to temperature (Rao \& Bullock 1954).

Other responses of reptiles to temperature, such as thermal dependence of sensory functions (Adrian et al. 1938, Patterson et al. 1968), neural function (Andry et al. 1971) and even learning (Krekorian et al. 1968), may also occur in sea turtles.

In this study, we examined changes in the dive behaviour of female hawksbill turtles following longterm, natural temperature fluctuations over a 2 yr remigration interval in the Caribbean Sea. This is the longest continuous record of sea turtle diving behaviour to date.

\section{MATERIALS AND METHODS}

Between 1 and 15 September 1999, 6 female hawksbill turtles were fitted with time-depth recorders (TDRs) while nesting at Buck Island Reef National Monument $\left(64^{\circ} 37^{\prime} \mathrm{W}, 17^{\circ} 47^{\prime} \mathrm{N}\right)$. This protected, uninhabited island is $1.6 \mathrm{~km}$ long and $0.8 \mathrm{~km}$ wide, situated $2.7 \mathrm{~km}$ northeast of St. Croix, US Virgin Islands, and serves as a nesting ground for approximately 120 hawksbill turtles.

We attached 4 TDRs to females that (based on longterm monitoring data collected by the Buck Island Reef Sea Turtle Research Program: initiated in 1988 under the supervision of the National Park Service at Christiansted, St. Croix, US Virgin Islands, to study the endangered hawksbill turtle) were expected to re-nest after $2 \mathrm{yr}$, i.e. in 2001. The body masses of these turtles were $72.5 \mathrm{~kg}$ (Turtle Ref. No. QQD 280), $77.0 \mathrm{~kg}$ (QQD 048), $80.5 \mathrm{~kg}$ (QQD 132) and $95.0 \mathrm{~kg}$ (QQD 401). In previous years, 2 other instrumented females had shown longer and irregular re-migration intervals, and 1 of these returned in 2003 (analysis of recorded data still pending).
The TDRs (Mk7, Wildlife Computers) recorded light intensity, temperature and dive depth, allowing temperature measurements over a range from -40 to $60^{\circ} \mathrm{C}$ with a resolution of $0.1^{\circ} \mathrm{C}$. Depth readings to a depth of $19.75 \mathrm{~m}$ were saved with a resolution of $0.5 \mathrm{~m}$; between 20 and $99.75 \mathrm{~m}$ the resolution was $1 \mathrm{~m}$, and dives deeper than $100 \mathrm{~m}$ were recorded with a resolution of $5 \mathrm{~m}$. Depth was recorded at intervals of $30 \mathrm{~s}$, while temperature was measured every $900 \mathrm{~s}$. For 3 TDRs, the accuracy of the time measurements was $<11 \mathrm{~min}$ after $2 \mathrm{yr}$ of operation (i.e. a maximum inaccuracy of $<0.0006 \mathrm{~s} \mathrm{~min}^{-1}$ ).

The Mk7 incorporates a 2 MB non-volatile Flash EEPROM for data storage. To cover a period of approx. 22 mo (the estimated duration of 1 re-migration interval) it was necessary to employ a duty cycle: the devices were programmed to store data for $2 \mathrm{~d}$, then stop for $4 \mathrm{~d}$ and to cycle these shifts until the memory was complete. The TDRs measured $2.2 \times 10.7 \times 1.2 \mathrm{~cm}$ and weighed ca. $35 \mathrm{~g}$ in air $(<0.05 \%$ of mean turtle body mass).

The devices were attached while the females were at the nesting beach. After egg-laying commenced, marginal scutes 10 and 11 on both sides of the carapace were checked to find the optimal attachment area. The serrated scutes were examined from below with a strong flashlight to verify the borderline between live tissue (incorporating bone) and noninnervated, translucent keratin. We drilled 2 holes (diameter $4 \mathrm{~mm}$ ) dorso-ventrally into the keratin using a hand-held cordless drill. The surface of the scutes at the attachment area was sanded with coarse sandpaper, and a small amount of epoxy resin (R-Kex ${ }^{\circledR}$, synonym Foil-Fast ${ }^{\circledR}$, Rawl, which cures within approx. $30 \mathrm{~min}$ ) was applied between the holes to fill in the gaps between the data logger and the uneven surface of the scutes. The Mk7 was positioned and held in place by 2 stainless steel bolts (4 $\mathrm{mm}$ diameter $\times 30 \mathrm{~mm}$ ) that were inserted into the holes from below; 2 self-securing nuts were tightened from above. Finally, the Mk7 was surrounded by fast-setting epoxy putty (repair stick ST115 steel, WEICON $^{\circledR}$ worldwide, which cures within approx. $5 \mathrm{~min}$ ) to even the edges and provide an instant support before the $\mathrm{R}-\mathrm{Kex}^{\circledR}$ bonded. All edges were shaped to minimise drag.

The data analysed in this paper include the regular patterns of nocturnal resting and diurnal activity while at the foraging grounds. Times of nesting activity and migratory behaviour are excluded due to their divergent diurnal behaviour pattern (Storch et al. 2003). The temperature data were used to calculate a mean temperature for each dive event (surface period excluded to avoid the effects of evaporative cooling and heating by radiation). 
To exclude short submersions or events of waves rolling over a surfacing turtle, a dive was defined as a submergence beyond a depth of $2 \mathrm{~m}$. However, the duration of a true dive event was then calculated as the time the turtle spent at depths of $\geq 50 \mathrm{~cm}$ in order to include the beginning of the descent and the end of the ascent phase in the dive duration.

Data recorded between 06:00 and 17:59.5 h (local time) are referred to as daytime data, those between 18:00 and 05:59.5 h (local time) as night-time data. Seasonal shifts in sunrise and sunset (within $1 \mathrm{~h}$ ) and the effects of turtle movement on the onset and end of daylight (ca. 45 min, cf. Storch 2003) were neglected as these were considered minor compared to the $12 \mathrm{~h}$ duration of day and night phases, and furthermore were found to be less than the duration of 1 or 2 dives. As no direct recordings of swimming speed were taken, we used vertical velocity as an indirect measure for active swimming-stroke effort during ascent and descent (Hays et al. 2004). The vertical velocity (which does not necessarily equate with swimming speed as dive angle was not taken into account) was calculated as the rate of change of depth $\left(\mathrm{m} \mathrm{s}^{-1}\right)$, and maximum values per dive are given. The expression 'dive depth', as used herein, refers to the maximum depth reached during a dive event. Regression lines are based on least-squares methodology.
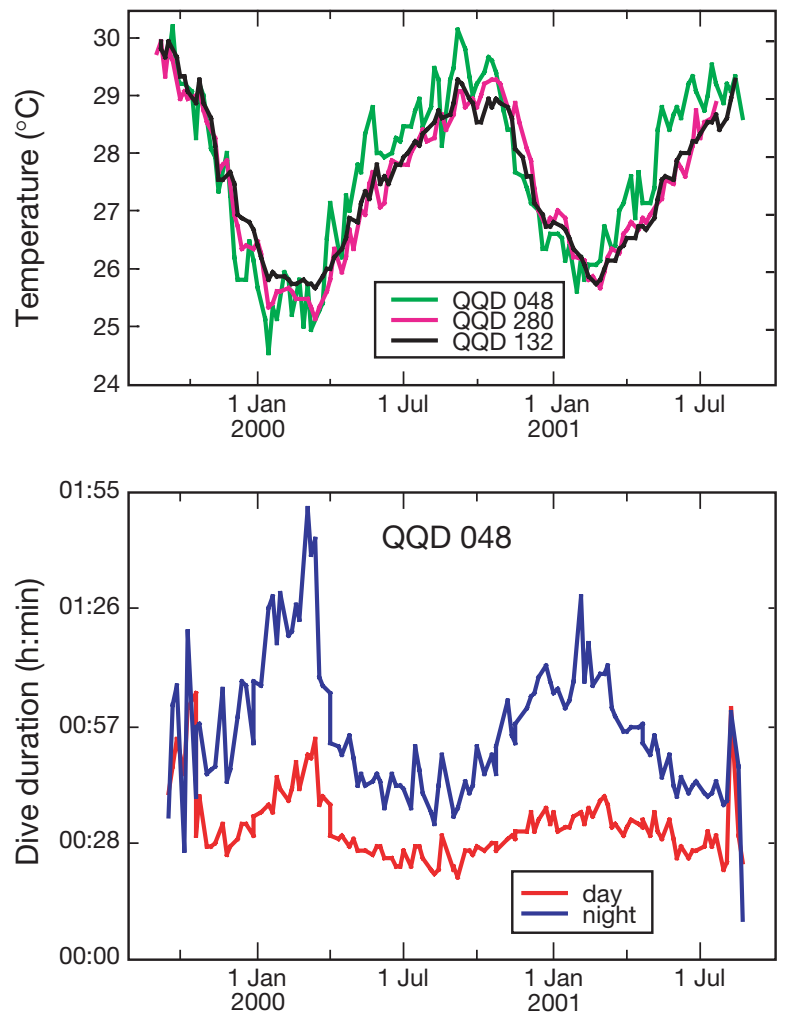

Table 1. Eretmochelys imbricata. Time and depth (mean $\pm \mathrm{SE})$ recordings for 3 female hawksbill turtles during re-migration

\begin{tabular}{|lccrr|}
\hline Turtle No. & Start & End & \multicolumn{1}{c}{$\begin{array}{c}\text { Depth } \\
(\mathrm{m})\end{array}$} & $\begin{array}{c}\text { No. of } \\
\text { dives }\end{array}$ \\
\hline QQD 280 & 18 Sep 1999 & 23 Jul 2001 & $21.1 \pm 7.0$ & 6233 \\
QQD 048 & 19 Oct 1999 & 24 Aug 2001 & $8.8 \pm 2.7$ & 8248 \\
QQD 132 & 31 Oct 1999 & 04 Sep 2001 & $27.7 \pm 8.8$ & 6647 \\
\hline
\end{tabular}

\section{RESULTS}

The 4 turtles expected to re-nest after a 2 yr remigration interval were observed at Buck Island between July and September 2001. TDRs were retrieved from 3 individuals (QQD 280, QQD 048 and QQD 132) while no evidence of the device or the attachment materials could be found on the carapace of the fourth (QQD 401). Successful recordings of re-migration behaviour of up to 22 mo were obtained (Table 1). During the phase of the stationary foraging behaviour analysed here, the instrumented turtles usually performed dives to depths of $<30 \mathrm{~m}$ (Table 1). Diurnal patterns in the dive profiles were found with nocturnal dives (between 18:00 and 05:59) characterised by flat bottom-phases and diurnal dives (between 6:00 and 17:59) showing frequent depth variations during the bottom time (cf. Storch 2003, Storch et al. 2003).
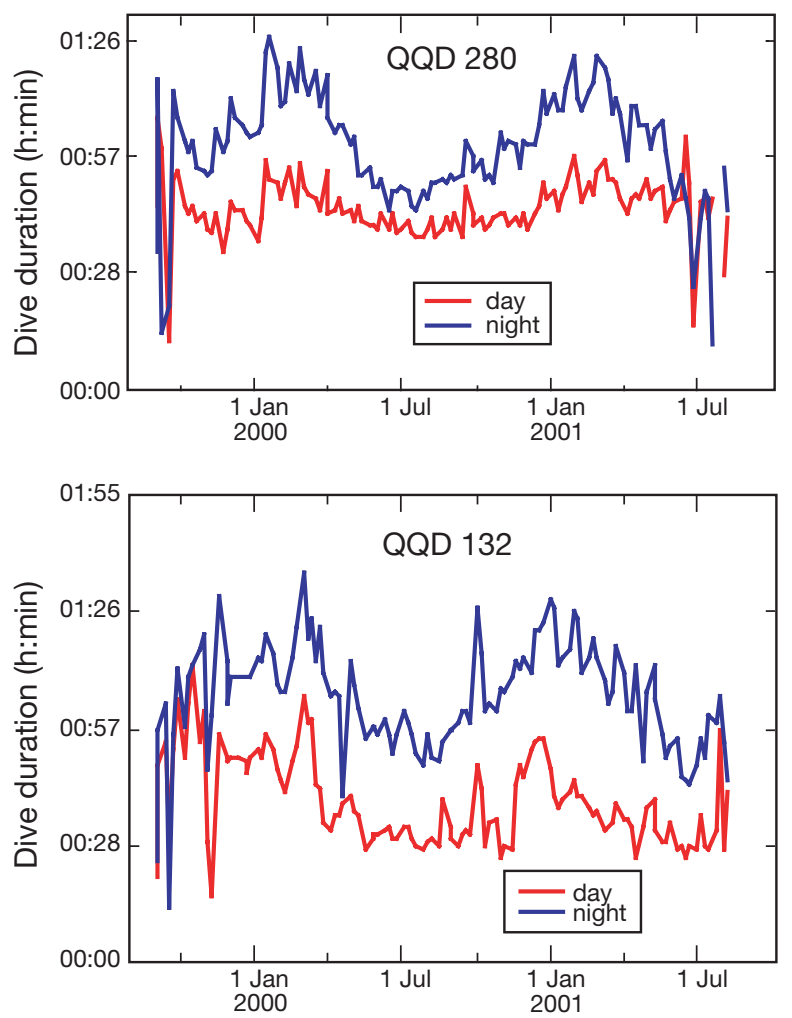

Fig. 1. Daily mean water temperature recorded by MK7 time-depth recorders (TDRs) attached to 3 female hawksbill turtles (Eretmochelys imbricata: QQD 280, QQD 048 and QQD 132) over a period of 22 mo and daily mean dive duration for day and night dives 


\section{Temperature fluctuations and dive duration}

Data from the 3 recovered MK7 TDRs showed seasonal fluctuations in water temperature (Fig. 1) over the 22 mo observation period. Although the turtles moved to different feeding grounds after the 1999 egg-laying season (Storch et al. 2003) all 3 individuals experienced parallel temperature changes. The minimum and maximum recorded temperatures were 24.1 and $31.4^{\circ} \mathrm{C}$, respectively. As the sampling interval of temperature measurements was long (15 min) we could not expect to see clear temperature gradients within single dive events. We did, however, occasionally obtain surface temperatures when the turtle happened to be at or near the surface at the time of data recording. These recordings showed an increase of up to $2^{\circ} \mathrm{C}$ compared with the temperature at depth during the day, while the difference was only approx. $0.4^{\circ} \mathrm{C}$ at night. During the dives, the temperature data did not show any trend in relation to the actual depth of the turtle.

The diving behaviour was very regular and uniform over the period of feeding away from the reproduction site, whereas nesting and migratory behaviour led to distinct behavioural patterns that were much more complex (Storch et al. 2003). For the analysis, we excluded these complex patterns and only used the data obtained during the described period of feeding of each individual, resulting in a total of 18955 dives.

Dive duration was negatively correlated with water temperature, with increased submergence times at lower temperatures (Fig. 1).

This change in dive duration was particularly evident between winter and summer conditions and especially during the night.

The least-squares fit calculated for the dive duration as a function of temperature showed a strong effect of temperature on nocturnal submergence times at temperatures below $28^{\circ} \mathrm{C}$ (Fig. 2), while at temperatures between 28 and $30^{\circ} \mathrm{C}$ the curve appeared to level off. By means of a piecewise linear regression, this point of inflection was located at $27.8^{\circ} \mathrm{C}$, with corresponding linear regressions at either side of the break point describing the temperature dependence of the nocturnal dive duration (Fig. 3). Dive duration as a function of temperature showed a strong effect of temperature on nocturnal submergence times at temperatures up to $27.8^{\circ} \mathrm{C}$ (Fig. $3, F=1172.7$, $\mathrm{p}<0.0001, \mathrm{n}=4104)$. At temperatures above $27.8^{\circ} \mathrm{C}$, changes in dive duration were not significant $(F=1.8$, $\mathrm{p}=0.177, \mathrm{n}=2963$ ). Temperature effects on daytime dive duration were significant $(F=1782.2, \mathrm{p}<0.0001$, $\mathrm{n}=11914$ ), but much less distinct than at night (Fig. 2).
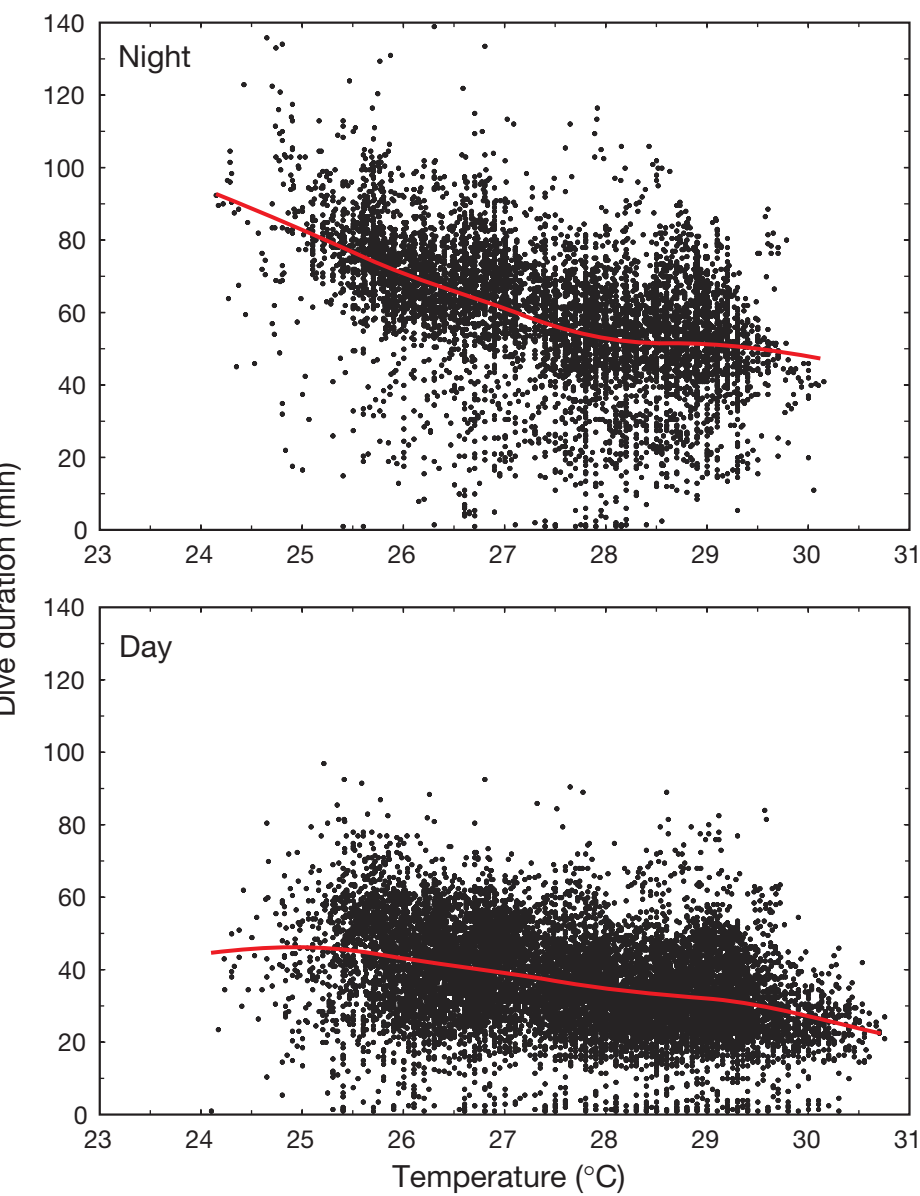

Fig. 2. Eretmochelys imbricata. Nocturnal and diurnal dive duration in relation to water temperature. Red lines represent curves fitted to data using the least-squares smoothing procedure, indicating a point of inflection in temperature-dependency of nocturnal dive duration

\section{$Q_{10}$}

Assuming that the nocturnal dives of the turtles are resting dives, during which they reduce their activity to a minimum (Storch et al. 2003), night dive duration can be used as a relative measure of metabolic rate. We accordingly calculated a resting $Q_{10}\left(\mathrm{R}_{1} Q_{10}\right)$ of 4.5 for temperatures below $27.8^{\circ} \mathrm{C}$, whereas the $Q_{10}$ above $27.8^{\circ} \mathrm{C}\left(\mathrm{R}_{2} Q_{10}\right)$ was 1 (no significant thermal dependence). The $Q_{10}$ resulting from the mostly active submergence times during daylight hours $\left(\mathrm{A}_{10}\right)$ was 2.3.

\section{Vertical velocity and dive depth}

The means of the peak vertical velocities during the descent and ascent were $0.37 \mathrm{~m} \mathrm{~s}^{-1}($ SD $0.19, \mathrm{n}=6793$ ) and $0.31 \mathrm{~m} \mathrm{~s}^{-1}$ (SD 0.15, $\mathrm{n}=6953$ ), respectively. For the 3 turtles engaged in nocturnal dives at the foraging grounds, we did not find a relationship between ver- 


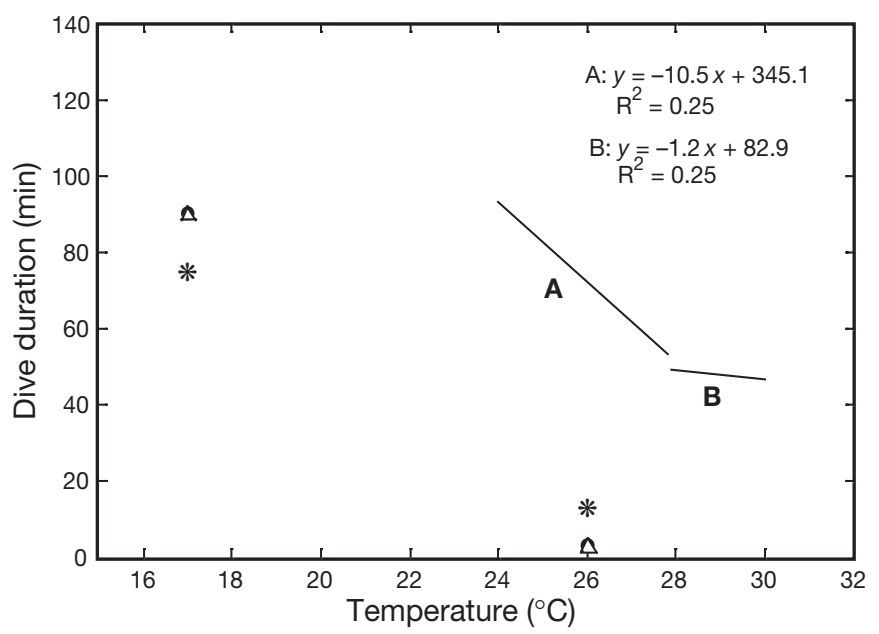

Fig. 3. Eretmochelys imbricata. Piecewise linear regression modelling temperature-dependency of dive duration (lines). $\mathrm{A}$ and $\mathrm{B}$ show trends for lower $\left(\mathrm{A}: \leq 27.8^{\circ} \mathrm{C}\right)$ and higher $(\mathrm{B}$ : $\left.>27.8^{\circ} \mathrm{C}\right)$ temperatures. Data points $\left(\Delta_{1} \bullet, *\right)$ show modal dive duration of 3 green turtles Chelonia mydas in the Mediterranean at pre-wintering $\left(26^{\circ} \mathrm{C}\right)$ and wintering $\left(17^{\circ} \mathrm{C}\right)$ temperatures (Godley et al. 2002) for comparison (see 'Discussion') turtles tended to reside in shallow areas near oceanic islands, whereas the large-scale data were taken by offshore ships. By extracting only the phase of stationary foraging in the feeding grounds, all events of basking behaviour (as observed during the migratory phases, see Storch 2003) and therefore excessive heating of the TDR through solar radiation were excluded from the analysis presented here. The sampling rate used to record the temperature data was insufficient to describe vertical thermal gradients. However, our devices occasionally recorded an increase in temperature when the turtles were at or near the surface. This increase is likely to have been caused by solar radiation rather than by a genuine vertical gradient in water temperature because these differences were not found at night. Because of the short duration of the surfacing events of the 3 turtles at the foraging grounds (mean $2.5 \mathrm{~min}, \mathrm{~S}$. Storch unpubl. data) and the thermal inertia of the body of large animals (Spotila \& Standora 1985), these differences in ambient water temperature should have had a negligible effect on the body temperature of the turtles. tical velocity and water temperature within the observed temperature range for either the descent or ascent (Fig. 4). However, we cannot exclude the possibility that such a dependency exists at temperatures beyond the range encountered in this study. The turtles performed resting dives to specific depth levels, which did not show any systematic variation over the water temperature range (Fig. 5). Due to the different feeding grounds visited by the fitted turtles (Storch et al. 2003), the total range of temperatures experienced differed by approx. $2^{\circ} \mathrm{C}$.

\section{DISCUSSION}

\section{Temperature fluctuations and dive duration}

The temperatures recorded by the TDRs follow the same trends as the official large-scale data for the sea-surface temperature in the region of the Antilles published in previous years (Table 2), with mostly corresponding values. Our recorded maximum temperatures in late summer, however, appear to be 1 to $2^{\circ} \mathrm{C}$ higher than the published large-scale temperatures. This is because the fitted

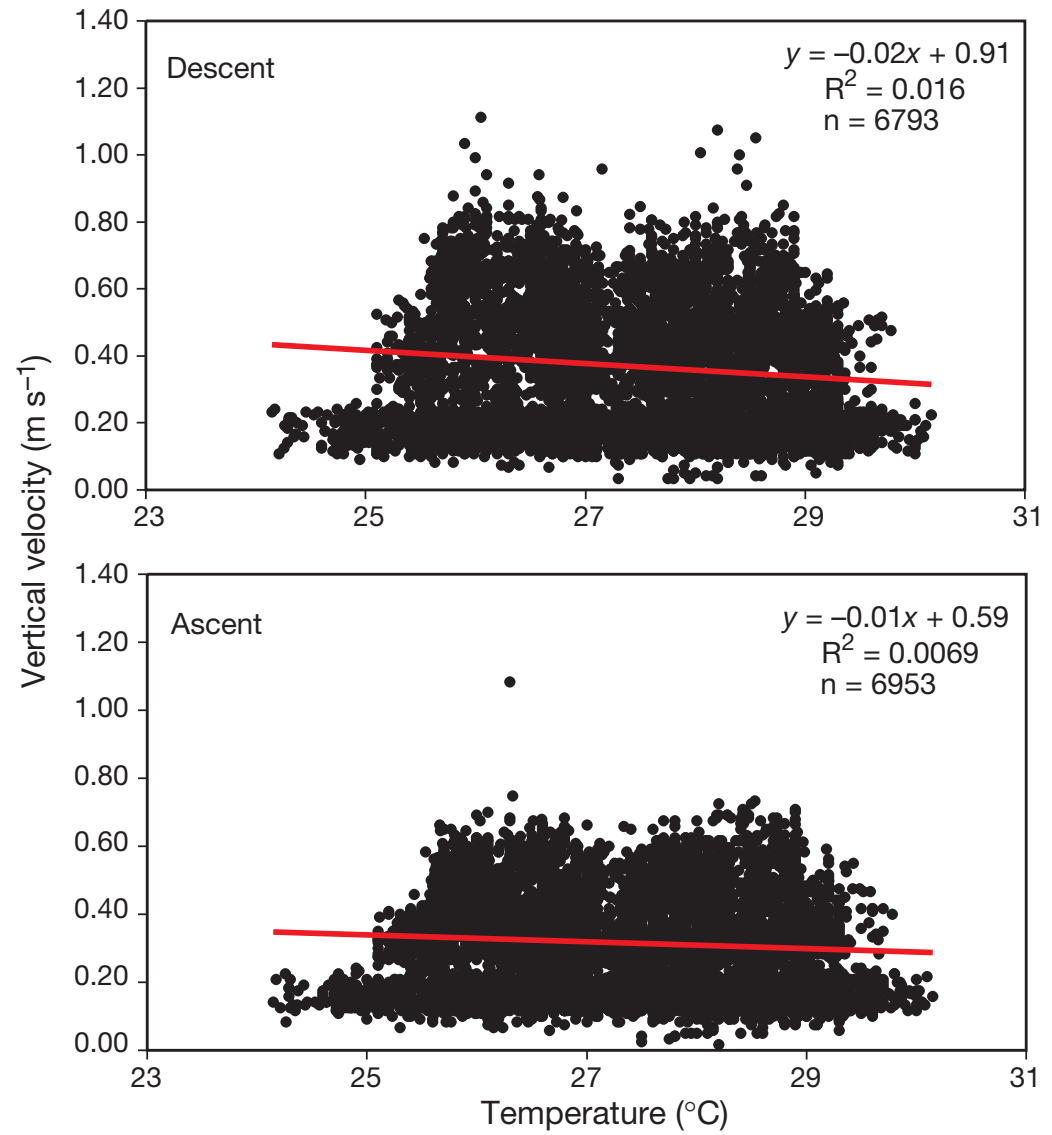

Fig. 4. Eretmochelys imbricata. Thermal independence of vertical velocity during descent and ascent phases for females QQD 280, QQD 048 and QQD 132 (combined data). Red lines signify linear regressions 


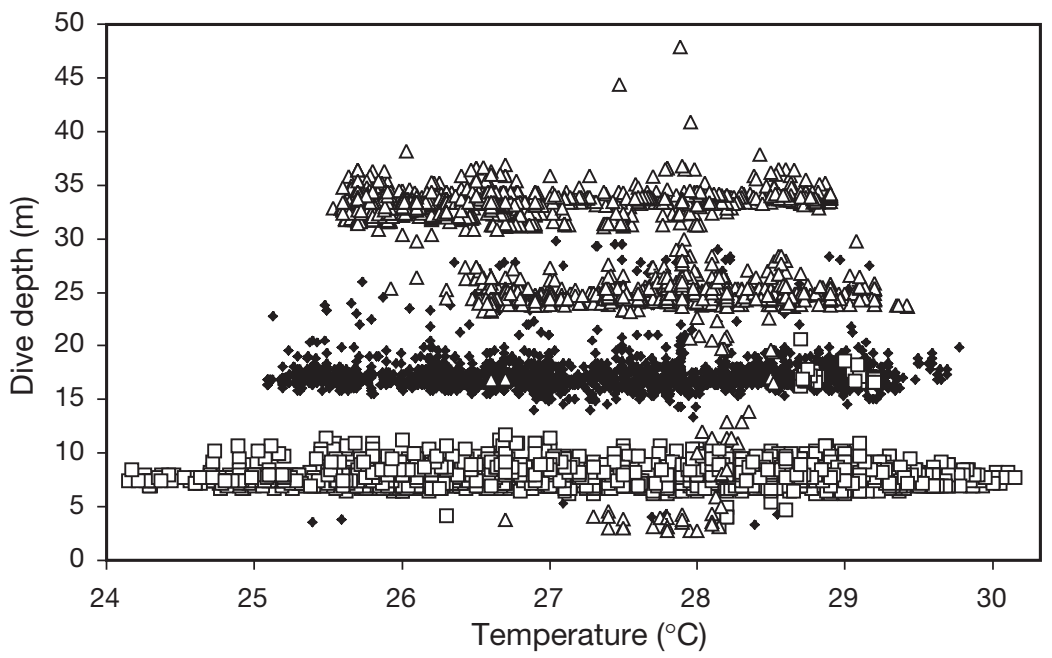

Fig. 5. Eretmochelys imbricata. Thermal independence of dive depth for females QQD $280(\bullet, \mathrm{n}=2316$, Pearson $\mathrm{r}=0.03)$, QQD $048(\square, \mathrm{n}=2607$, Pearson $\mathrm{r}=0.1)$ and QQD $132(\Delta, \mathrm{n}=2153$, Pearson $\mathrm{r}=-0.4)$. Clusters of data represent preferred depth levels of turtles during benthic resting dives during the dark hours between 18:00 and 05:59 h, and only actively swimming when they commuted to the surface to breathe. A strong thermal dependence of dive durations at temperatures below $27.8^{\circ} \mathrm{C}$ was found for the nocturnal resting dives of the instrumented turtles. As plotted in Fig. 3 for comparison, previously published long-term data (up to 293 d) obtained via satellite transmitters from 3 green turtles in the Mediterranean also revealed a seasonal change in dive duration (Godley et al. 2002). Modal dive duration of the instrumented green turtles was less than 5 min and between 10 and $15 \mathrm{~min}$ at temperatures around $26^{\circ} \mathrm{C}$, the submergence times increased to between 60 and $90 \mathrm{~min}$ when the temperatures declined to $17^{\circ} \mathrm{C}$ (Godley et al. 2002).

As hawksbill turtles are considered to be benthic feeders (Meylan 1988), the differences in mean dive depth (Table 1) most probably resulted from the specific ranges of water depth at the individual feeding grounds. Dives performed during the day were assumed to be associated with active benthic feeding, as they occurred at a variety of depths and showed depth variation within bottom-phases (Storch et al. 2002). In contrast, successive nocturnal dives were characterised by a very limited bottom-depth range (see also Hays et al. 2000), and were longer than dives made during the previous and following diurnal periods (Storch et al. 2003). We therefore conclude that the turtles were essentially resting

Table 2. Water temperatures recorded by TDRs on instrumented turtles in 2000 and 2001, and official large scale temperatures for the northern Caribbean Sea (Deutsches Hydrographisches Institut 1956, 1967, Bundesamt für Seeschiffahrt Hydrographie 1998)

\begin{tabular}{|lcccc|}
\hline \multirow{2}{*}{ Month } & \multicolumn{4}{c|}{ Water temperature $\left({ }^{\circ} \mathrm{C}\right)$} \\
\cline { 2 - 5 } & This study & 1956 & 1967 & 1998 \\
\hline January & $24-26$ & 26 & $25-26$ & 26 \\
February & $25-26$ & 25 & $25-26$ & 26 \\
March & $25-26$ & $25-26$ & $25-26$ & $24-26$ \\
April & $26-27$ & $25-26$ & $25-27$ & 26 \\
May & $27-28$ & 27 & $26-27$ & 26 \\
June & $28-29$ & $27-28$ & 27 & $26-28$ \\
July & $28-29$ & 27 & 27 & 26 \\
August & $28-29$ & 28 & 27 & 28 \\
September & $29-30$ & 28 & 28 & 28 \\
October & $29-30$ & $27-28$ & 28 & 28 \\
November & 29 & $27-28$ & $27-28$ & 26 \\
December & 28 & $26-27$ & $26-27$ & 26 \\
\hline
\end{tabular}

These data indicate a thermal dependence of dive duration in green turtles that is remarkably parallel to the steep part of our piecewise model obtained from hawksbill turtles. However, dive durations of the larger green turtles are rather short compared to the submergence times found in our study. As the confirmed natural temperature range experienced by hawksbill turtles extends from $15^{\circ} \mathrm{C}$ (J. A. Seminoff pers. comm., cf. Seminoff et al. 2003) to $32^{\circ} \mathrm{C}$ (A. Moore pers. comm.) additional data, especially at the lower end of the scale, would be needed to confirm the broader validity of the model and the possible further similarity to the slope found for green turtles.

Unrestrained and undisturbed turtles have been shown to breathe at a fairly constant level of depletion of their oxygen store (e.g. Burggren \& Shelton 1979, Lutcavage \& Lutz 1991). Assuming a mostly undisturbed nocturnal resting condition for our 3 individuals, submergence times at night are probably a function of the metabolic rate and its thermal dependence. In contrast, the different levels of activity that occur throughout the day could not be determined in this study. Such activities may substantially influence metabolic rate, oxygen depletion and ultimately dive duration. During the day, when dives are presumed to be mostly associated with active foraging, the relationship between water temperature and dive duration has a reduced gradient in the slope (Fig. 2). This enhanced independence probably stems from active sea turtles being able to maintain a body temperature that exceeds the water temperature due to muscular heating and thermal inertia (Sato et al. 1995, Hochscheid et al. 2002). 
$Q_{10}$

Piecewise linear regression analysis revealed that there is a point of inflection in the thermal dependence of the dive duration, leading to a high $\mathrm{R}_{1} Q_{10}$ value of 4.5 at temperatures below $27.8^{\circ} \mathrm{C}$, and a lack of significant temperature-dependence above $27.8^{\circ} \mathrm{C}$ (Fig. 3). The thermal dependence represents the sum of the $Q_{10}$ values for the different tissues of the sea turtle's body. Some exemplary tissues of the green turtle have been shown to have temperature-sensitive metabolic rates, with $Q_{10}$ values decreasing at higher temperatures (Penick et al. 1996). Studies of tissues of other reptiles revealed that metabolic rate increases dramatically with increasing temperature in the lower experimental range (4 to $20^{\circ} \mathrm{C}, Q_{10}$ of 6.5 ), but reach a metabolic plateau in the upper range $\left(20\right.$ to $34^{\circ} \mathrm{C}, Q_{10}$ approx. 2.0) (Hoskins \& Aleksiuk 1973). These findings are in agreement with our descriptive model (Fig. 3). Our $\mathrm{R}_{1} Q_{10}$ and $\mathrm{R}_{2} Q_{10}$ values frame the $Q_{10}$ value of 2.4 calculated from the oxygen consumption of unrestrained, captive loggerhead turtles kept in water between 10 and $30^{\circ} \mathrm{C}$ (Lutz et al. 1989). Typical $Q_{10}$ values found for reptiles are between 2 and 3 (Glass \& Wood 1983). Our $\mathrm{AQ}_{10}=2.3$ found during the daytime is well within this range.

However, cognisance must be taken of the fact that the relatively elevated body temperature of an active turtle during daylight does not equal that of the surrounding water (as reviewed in Spotila et al. 1996), which is the case for a resting turtle at night. Therefore, the temperature data included in the calculation of the $A Q_{10}$ are probably incorrect with regard to body temperature.

Satellite telemetry, as used by Godley et al. (2002), did not reveal the chronology of the depth data, but integrated diving information from $6 \mathrm{~h}$ periods into a histogram. Therefore the data from Godley et al. (2002) did not provide insight into day- or night-time diving behaviour and flat bottom-resting dives could not be separated from obviously active dives. However, the data obtained from the 3 green turtles included in Fig. 3 for comparison show a trend that supports our proposed model, even though the routine dive duration of green turtles is shorter than the submergence durations of the hawksbill turtles (Hays et al. 2000, 2002).

\section{Vertical velocity and dive depth}

A decrease in environmental temperature has been shown to decrease the locomotor performance of ectotherms (Hirano \& Rome 1984, Du et al. 2000). Moreover, vertical velocity, a measure of the degree of active power-stroking during ascent and descent, should also decrease in response to cold water (cf. Skrovan et al. 1999). However, our data failed to show a corresponding temperature-dependent change in maximum vertical velocity of the instrumented sea turtles (Fig. 4). While our findings contradict the expected results, previous studies of submaximal performance have shown cases of thermal independence of muscle output in cold-blooded animals (Rome 1982, Rome \& Loughna 1983 in Hirano \& Rome 1984). The conclusion of the results found in running lizards and swimming carp is that at low temperatures a higher number of muscle fibres and a selection of faster fibres contributes invariant locomotion speeds at 10 and $20^{\circ} \mathrm{C}$ (Rome \& Loughna 1983).

Fig. 5 clearly shows clusters of levels of dive depth, representing depth preferences of the tagged turtles. Hawksbill turtles are known to dive serially to habitual sites within the reef (van Dam \& Diez 1997). The absence of a relationship between water temperature and dive depth (Fig. 5) supports the model in Fig. 3, and discounts this possibility as a cause of the observed thermal dependence of submergence times.

\section{Effects of temperature changes}

Although sea turtles should be able to mostly avoid unacceptable temperatures through migration, they still experience water temperatures which fluctuate over several degrees Celsius. This has been shown for the most tropical of all species, the hawksbill turtle. At higher water temperatures, hawksbill turtles have to surface more often, thus exposing themselves to a greater risk of being affected by human impact (e.g. being approached and disturbed or hit by a boat) or of being attacked by sharks (M. Heithaus pers. comm., cf. Strong 1996), with the tiger shark Galeocerdo cuvier being the only predator that is specialised to take large cheloniid turtles (Witzell 1987). The generally low metabolism of cold-blooded animals such as reptiles probably contributes to the longevity of these animals (Jonsson 1991). Full torpor or hibernation, as discussed or observed in other species (e.g. Felger et al. 1976, Carr et al. 1980) are irrelevant for the hawksbill turtle, as this species neither experiences temperatures below $10^{\circ} \mathrm{C}$ nor a seasonal shortage of food.

Overall, our data indicate that a substantial change in ocean water temperature would influence sea turtles. Levitus et al. (2000) found an increase in the temperature of the upper $300 \mathrm{~m}$ of the water column of $0.31^{\circ} \mathrm{C}$ over the last $45 \mathrm{yr}$. There is evidence that the primary cause of this change is anthropogenic global warming rather than climate variability (Levitus et al. 2000). Based on our model, this warming should shorten the 
resting dive duration by about 3 min at water temperatures below $28^{\circ} \mathrm{C}$, while at higher temperatures the effect would be much less (15 s). Although we were able to detect temperature-dependent dive duration in the instrumented hawksbill turtles, the full consequences of changes in water temperature for this species are hard to foresee. Certainly, as longevity seems to be related to metabolic rate (Jonsson 1991), small increases in water temperature may decrease life expectancy and hence the number of breeding attempts. In the context of climate changes, the effects of rising sea level and increased incubation temperatures might lead to an even more serious disturbance to the life cycle of hawksbill turtles. The fairly substantial changes in water temperature associated with the El Niño phenomenon (e.g. Elliott et al. 2001) may facilitate favourable conditions for further studies of the temperature-dependency of marine turtle diving behaviour.

Acknowledgements. All research was conducted under licence (permit to Z. M. Hillis-Starr). This work was funded through a grant to R.P.W. from the Deutsche Forschungsgemeinschaft (Wi 1023/5-1 and Wi 1023/5-2). We thank C. Begler and S. Zankl for help with the computer programme MATLAB. The study greatly benefited from the NPS staff and volunteers at Buck Island Reef NM. We are grateful to 3 anonymous referees for valuable comments on the manuscript.

\section{LITERATURE CITED}

Adrian ED, Sturdy RS, Craik KJW (1938) The electrical response of the auditory mechanism in cold-blooded vertebrates. Proc R Soc Lond Ser B 125:435-455

Andry ML, Luttges MW, Gamow RI (1971) Temperature effects on spontaneous and evoked neural activity in the garter snake. Exp Neurol 31:32-44

Bundesamt für Seeschiffahrt und Hydrographie (1998) Monatskarten für den Nordatlantik. Bundesamt, Hamburg

Burggren WW, Shelton G (1979) Gas exchange and transport during intermittent breathing in chelonian reptiles. J Exp Biol 82:75-92

Carr A, Ogren L, McVea C (1980) Apparent hibernation by the atlantic loggerhead turtle Caretta caretta off Cape Canaveral, Florida. Biol Conserv 19:7-14

Davenport J (1998) Sustaining endothermy on a diet of cold jelly: energetics of the leatherback turtle Dermochelys coriacea. Br Herpetol Soc Bull 62:4-8

Deutsches Hydrographisches Institut (1956) Monatskarten für den Nordatlantik. Deutsches Hydrographisches Institut, Hamburg

Deutsches Hydrographisches Institut (1967) Monatskarten für den Nordatlantik. Deutsches Hydrographisches Institut, Hamburg

Du WG, Yan SJ, Ji X (2000) Selected body temperature, thermal tolerance and thermal dependence of food assimilation and locomotor performance in adult blue-tailed skinks, Eumeces elegans. J Therm Biol 25:197-202

Elliott JR, Jewson SP, Sutton RT (2001) The impact of the 1997/98 El Niño event on the Atlantic Ocean. J Climatol 14:1069-1077
Felger RS, Cliffton K, Regal PJ (1976) Winter dormancy in sea turtles: independent discovery and exploitation in the Gulf of California by two local cultures. Science 191:283-285

Girgis S (1961) Aquatic respiration in the common Nile turtle Trionyx triunguis (Forskal). Comp Biochem Physiol 3: 206-217

Glass ML, Wood SC (1983) Gas exchange and control of breathing in reptiles. Physiol Rev 63:232-260

Godley BJ, Richardson S, Broderick AC, Coyne MS, Glen F, Hays G (2002) Long-term satellite telemetry of the movements and habitat utilisation by green turtles in the Mediterranean. Ecography 25:352-362

Hays GC, Adams CR, Broderick AC, Godley BJ, Lucas DJ, Metcalfe JD, Prior AA (2000) The diving behaviour of green turtles at Ascension Island. Anim Behav 59:577-586

Hays GC, Broderick AC, Glen F, Godley BJ, Houghton JDR, Metcalfe JD (2002) Water temperature and internesting intervals for loggerhead (Caretta caretta) and green (Chelonia mydas) sea turtles. J Therm Biol 27:429-432

Hays G, Metcalfe JD, Walne AW, Wilson RP (2004) First records of flipper movements during sea turtle diving. J Exp Mar Biol Ecol 303:243-260

Heath ME, McGinnis SM (1980) Body temperature and heat transfer in the green sea turtle Chelonia mydas. Copeia 1980:767-773

Hirano M, Rome LC (1984) Jumping performance of frogs (Rana pipiens) as a function of muscle temperature. J Exp Biol 108:429-439

Hochscheid S, Bentivegna F, Speakman JR (2002) Regional blood flow in sea turtles: implications for heat exchange in an aquatic ectotherm. Physiol Biochem Zool 75:66-76

Hoskins MA, Aleksiuk M (1973) Effects of temperature, photoperiod and season on in vitro metabolic rates of tissues from Thamnophis sirtalis parietalis, a cold climate reptile. Comp Biochem Physiol A45:737-756

Jackson DC, Prange HD (1979) Ventilation and gas exchange during rest and exercise in adult green sea turtles. J Comp Physiol 134:315-319

Jonsson B (1991) Longevity, body size, and growth in anadromous brown trout (Salmo trutta). Can J Fish Aquat Sci 48: 1838-1845

Krekorian CO, Vance VJ, Richardson AM (1968) Temperature-dependent maze learning in the desert iguana, Dipsosaurus dorsalis. Anim Behav 16:429-436

Levitus S, Antonov JI, Boyer TP, Stephens C (2000) Warming of the world ocean. Science 287:2225-2229

Lutcavage ME, Lutz PL (1991) Voluntary diving metabolism and ventilation in the loggerhead sea turtle. J Exp Mar Biol Ecol 147:287-296

Lutz PL, Bentley TB (1985) Respiratory physiology of diving in the sea turtle. Copeia 1985:671-679

Lutz PL, Bergey A, Bergey M (1989) Effects of temperature on gas exchange and acid-base balance in the sea turtle Caretta caretta at rest and during routine activity. J Exp Biol 144:155-169

Meylan A (1988) Spongivory in hawksbill turtles: a diet of glass. Science 239:393-395

Moon DY, Mackenzie DS, Owens DW (1997) Simulated hibernation of sea turtles in the laboratory: I. Feeding, breathing frequency, blood $\mathrm{pH}$, and blood gases. J Exp Biol 278: $372-380$

Paladino FV, O'Connor MP, Spotila JR (1990) Metabolism of leatherback turtles, gigantothermy, and thermoregulation of dinosaurs. Nature 344:858-860

Patterson WC, Evering FC, McNall CL (1968) The relationship of temperature to the cochlear response in a poikilotherm. J Aud Res 8:439-448 
Penick DN, Paladino FV, Steyermark AC, Spotila JR (1996) Thermal dependence of tissue metabolism in the green turtle, Chelonia mydas. Comp Biochem Physiol A113: 293-296

Priest TE, Franklin CE (2002) Effect of water temperature and oxygen levels on the diving behavior of two freshwater turtles: Rheodytes leukops and Emydra macquarii. J Herpetol 36:555-561

Rao KP, Bullock TH (1954) $\mathrm{Q}_{10}$ as a function of size and habitat temperature in poikilotherms. Am Nat 88:33-44

Rome LC (1982) Energetic costs of running with different muscle temperatures in Savannah monitor lizards. J Exp Biol 99:269-277

Sato K, Sakamoto W, Matsuzawa Y, Tanaka H, Naito Y (1994) Correlation between stomach temperatures and ambient water temperatures in free-ranging loggerhead turtles, Caretta caretta. Mar Biol 118:343-351

Sato K, Sakamoto W, Matsuzawa Y, Tanaka H, Minamikawa S, Naito Y (1995) Body temperature independence of solar radiation in free-ranging loggerhead turtles, Caretta caretta, during internesting periods. Mar Biol 123:197-205

Sato K, Matsuzawa Y, Tanaka H, Bando T, Minamikawa S, Sakamoto W, Naito Y (1998) Internesting intervals for loggerhead turtles, Caretta caretta, and green turtles, Chelonia mydas, are affected by temperature. Can J Zool 76:1651-1662

Seminoff JA, Nichols WJ, Resendiz A, Brooks L (2003) Occurrence of hawksbill turtles, Eretmochelys imbricata (Reptilia: Cheloniidae), near the Baja California Peninsula, México. Pac Sci 57:9-16

Skoczylas R (1978) Physiology of the digestive tract. In: Gans C (ed) Biology of the Reptilia. Academic Press, New York, p 589-698

Skrovan RC, Williams TM, Berry PS, Moore PW, Davis RW (1999) The diving physiology of bottlenose dolphins

Editorial responsibility: Otto Kinne (Editor-in-Chief), Oldendorf/Luhe, Germany
(Tursiops truncatus). II. Biomechanics and changes in buoyancy at depth. J Exp Biol 202:2749-2761

Spotila JR, Standora EA (1985) Environmental constraints on the thermal energetics of sea turtles. Copeia 1985:694-702

Spotila JR, O'Connor MP, Paladino FV (1996) Thermal biology. In: Lutz PL, Musick JA (eds) The biology of sea turtles. CRC Press, Boca Raton, FL, p 297-341

Standora EA, Spotila JR, Foley RE (1982) Regional endothermy in the sea turtle, Chelonia mydas. J Therm Biol $7: 159-165$

Storch S (2003) The behaviour of immature and female hawksbill turtles (Eretmochelys imbricata) at Sea. PhD thesis, Christian-Albrechts-Universität, Kiel

Storch S, Hillis-Starr ZM, Wilson RP (2002) Things to do, places to be: internesting diving behavior of Caribbean hawksbill turtles elucidated through archival tags. In: Mosier A, Foley A, Brost B (eds) Proc 20th Annu Symp Sea Turtle Biology and Conservation. NOAA Tech Memo NMFS-SEFSC 477. US Dept. Commerce, Miami, FL, p 34-36

Storch S, Hillis-Starr ZM, Wilson RP (2003) Caribbean roundtrip ticket: the migration behavior of female hawksbill turtles recorded using data loggers. In: Seminoff JA (ed) Proc 22nd Annu Symp Sea Turtle Biology and Conservation. NOAA Tech Memo NMFS-SEFSC 503. US Dept. Commerce, Miami, FL, p 54-55

Strong WR Jr (1996) Shape discrimination and visual predatory tactics in white sharks. In: Ainley DG, Klimley AP (eds) Great white sharks: the biology of Carcharodon carcharias. Academic Press, New York, p 229-240

van Dam RP, Diez CE (1997) Diving behavior of immature hawksbill turtles (Eretmochelys imbricata) in a Caribbean reef habitat. Coral Reefs 16:133-138

Witzell WN (1987) Selective predation on large cheloniid sea turtles by tiger sharks (Galeocerdo cuvier). Jpn J Herpetol 12:22-29

Submitted: April 23, 2003; Accepted: August 19, 2004

Proofs received from author(s): May 9, 2005 